\title{
Front Matter: Volume 10623
}

, "Front Matter: Volume 10623," Proc. SPIE 10623, 2017 International Conference on Optical Instruments and Technology: IRMMW-THz Technologies and Applications, 1062301 (12 January 2018); doi: $10.1117 / 12.2317493$

SPIE Event: International Conference on Optical Instruments and Technology 2017, 2017, Beijing, China 


\section{PROCEEDINGS OF SPIE}

\section{International Conference on Optical Instruments and Technology \\ IRMMW-THz Technologies and Their Applications}

\section{Cunlin Zhang \\ Xi-Cheng Zhang \\ Zhiming Huang}

Editors

28-30 October 2017

Beijing, China

Sponsored by

$\mathrm{CIS}$ - China Instrument and Control Society (China)

SPIE

Published by

SPIE 
The papers in this volume were part of the technical conference cited on the cover and title page. Papers were selected and subject to review by the editors and conference program committee. Some conference presentations may not be available for publication. Additional papers and presentation recordings may be available online in the SPIE Digital Library at SPIEDigitalLibrary.org.

The papers reflect the work and thoughts of the authors and are published herein as submitted. The publisher is not responsible for the validity of the information or for any outcomes resulting from reliance thereon.

Please use the following format to cite material from these proceedings:

Author(s), "Title of Paper," in 2017 International Conference on Optical Instruments and Technology: IRMMW-THz Technologies and Their Applications, edited by Cunlin Zhang, Xi-Cheng Zhang, Zhiming Huang, Proceedings of SPIE Vol. 10623 (SPIE, Bellingham, WA, 2018) Seven-digit Article CID Number.

ISSN: 0277-786X

ISSN: 1996-756X (electronic)

ISBN: 9781510617575

ISBN: 9781510617582 (electronic)

Published by

SPIE

P.O. Box 10, Bellingham, Washington 98227-0010 USA

Telephone +1 3606763290 (Pacific Time) · Fax +1 3606471445

SPIE.org

Copyright (C) 2018, Society of Photo-Optical Instrumentation Engineers.

Copying of material in this book for internal or personal use, or for the internal or personal use of specific clients, beyond the fair use provisions granted by the U.S. Copyright Law is authorized by SPIE subject to payment of copying fees. The Transactional Reporting Service base fee for this volume is $\$ 18.00$ per article (or portion thereof), which should be paid directly to the Copyright Clearance Center (CCC), 222 Rosewood Drive, Danvers, MA 01923. Payment may also be made electronically through CCC Online at copyright.com. Other copying for republication, resale, advertising or promotion, or any form of systematic or multiple reproduction of any material in this book is prohibited except with permission in writing from the publisher. The CCC fee code is 0277$786 \mathrm{X} / 18 / \$ 18.00$

Printed in the United States of America.

Publication of record for individual papers is online in the SPIE Digital Library.

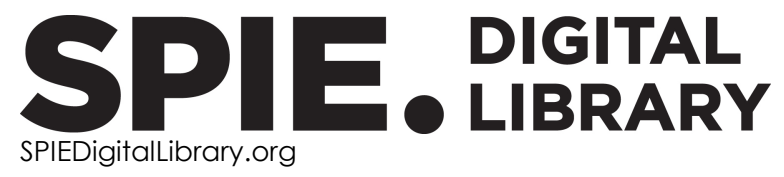

Paper Numbering: Proceedings of SPIE follow an e-First publication model. A unique citation identifier (CID) number is assigned to each article at the time of publication. Utilization of CIDs allows articles to be fully citable as soon as they are published online, and connects the same identifier to all online and print versions of the publication. SPIE uses a seven-digit CID article numbering system structured as follows:

- The first five digits correspond to the SPIE volume number.

- The last two digits indicate publication order within the volume using a Base 36 numbering system employing both numerals and letters. These two-number sets start with 00, 01, 02, 03, 04, 05, 06, 07, 08, 09, OA, OB ... 0Z, followed by 10-1Z, 20-2Z, etc. The CID Number appears on each page of the manuscript. 


\title{
Contents
}

\author{
$\checkmark \quad$ Authors \\ vii Symposium Committee \\ ix Conference Committee \\ xi Introduction \\ xiii Conference Organizers
}

\section{SESSION 1 IRMMW-THZ TECHNOLOGIES AND THEIR APPLICATIONS I}

1062302 Corrugated metal surface with pillars for terahertz surface plasmon polariton waveguide components [10623-36]

1062303 THz computed tomography system with zero-order Bessel beam [10623-39]

1062304 Manipulating the strength and broadband of the resonators in the terahertz metamaterials [10623-37]

1062305 A debugging method of the Quadrotor UAV based on infrared thermal imaging [10623-44]

SESSION 2 IRMMW-THz TECHNOLOGIES AND THEIR APPLICATIONS II

1062306 Terahertz carpet cloak based on ultrathin metasurface [10623-41]

1062307 All-dielectric band stop filter at terahertz frequencies [10623-10]

1062308 Compact terahertz spectrometer based on disordered rough surfaces [10623-13]

\section{POSTER SESSION}

1062309 Stimulation research on the measurement of the IRW pneumatic thermal radiation [10623-3]

10623 OA Research on terahertz properties of rat brain tissue sections during dehydration [10623-8]

10623 OB Optical constant determination of cross-linked polystyrene in the infrared [10623-11]

10623 OC Nonlinear bias analysis and correction of microwave temperature sounder observations for FY-3C meteorological satellite [10623-14] 
10623 OD Switchable tri-band THz polarizing rotator based on chiral metamaterials [10623-16]

10623 OE Scattering properties of electromagnetic waves from metal object in the lower terahertz region [10623-18]

10623 OF A simple system for $160 \mathrm{GHz}$ optical terahertz wave generation and data modulation [10623-25]

$106230 \mathrm{~T}$ The preparation method of terahertz monolithic integrated device [10623-27]

$10623 \mathrm{OH} \quad$ Hydrothermal preparation of vanadium dioxide thin films and research progress of terahertz modulation [10623-28]

10623 Ol Quantitative detection of melamine based on terahertz time-domain spectroscopy [10623-29]

10623 OJ Detection of lonic liquid using terahertz time-domain spectroscopy [10623-30]

10623 OK Detailed real-time infrared radiation simulation applied to the sea surface [10623-33]

$10623 \mathrm{OL}$ Removing the echoes from terahertz pulse reflection system and sample [10623-35]

10623 OM Studies on electromagnetic response in arc-shaped structures in terahertz region [10623-38]

$10623 \mathrm{ON}$ Characterizing the hydration state of L-threonine in solution using terahertz time-domain attenuated total reflection spectroscopy [10623-42]

$1062300 \quad$ Light field imaging and application analysis in THz [10623-43]

10623 OP Studies on the resonant properties in the asymmetric dipole-array terahertz metamaterials [10623-46]

$10623 \mathrm{OQ}$ Fabrication and performance of a double layered $\mathrm{Mn}-\mathrm{Co}-\mathrm{Ni}-\mathrm{O} / \mathrm{Mn}-\mathrm{Co}-\mathrm{Ni}-\mathrm{Cu}-\mathrm{O}$ thin film detector [10623-48]

10623 OR Study on THz wave generation from air plasma induced by quasi-square Airy beam [10623-50]

10623 OS Characterization of the terahertz frequency optical constants of tourmaline [10623-51]

10623 OT Integrated Mach-Zehnder interferometer on the end facet of multicore fiber for refractive index sensing application [10623-52]

$10623 \mathrm{OU}$ The improvement of surface roughness for OAP aluminum mirrors: from terahertz to ultraviolet [10623-53] 


\section{Authors}

Numbers in the index correspond to the last two digits of the seven-digit citation identifier (CID) article numbering system used in Proceedings of SPIE. The first five digits reflect the volume number. Base 36 numbering is employed for the last two digits and indicates the order of articles within the volume. Numbers start with 00, 01, 02, 03, 04, 05, 06, 07, 08, 09, OA, OB...0Z, followed by 10-12, 20-2Z, etc.

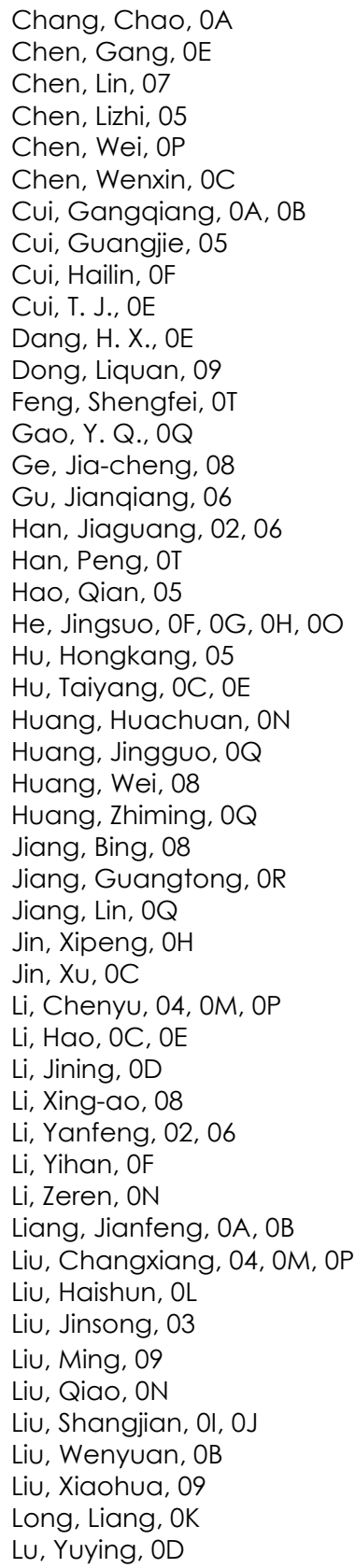

LV, Rongchuan, OC, OE

Niv, Liting, 03

Peng, Jilong, $\mathrm{OU}$

Peng, Wenyu, OB

Qi, Yanwen, OT

Qiao, Zhi, OB

Qu, Yue, $O Q$

Shao, Yajun, OU

Shi, Lan, OM, OP

Shi, Zexia, OF, $\mathrm{OH}$

SU, BO, OF, OG, OH, OO

Su, Xiang, OE

Sun, Huijuan, OM

Sun, Wenfeng, OT

Sun, Xueming, $\mathrm{OF}, \mathrm{OH}$

Tan, X. M., OE

Tang, Weichong, OS

Tian, Chunxiu, 02

Tu, Min, OB

Wang, Cuicui, Ol, OJ

Wang, Dong, OU

Wang, Kejia, 03

Wang, Ruike, $\mathrm{OF}, \mathrm{OH}$

Wang, Shanshan, OU

Wang, Xinke, OT

Wei, Minggui, 06

Wei, Yifang, 09

WU, Jing, $O Q$

WU, Limin, OK

Wu, Qiao, 03

Wu, Yaxiong, 0G, 00

Xiao, Ke, OS

Xu, Quan, 02

$\mathrm{Xu}$, Yuehong, 02

Yang, Jianguo, 05

Yang, Quanlong, 06

Yang, Tao, 08

Yang, Zhengang, 03

Yao, Jianquan, OD

Yao, Niangjuan, $0 Q$

Ye, Jiasheng, OT

Yi, Zhong, OU

Yin, Shan, 07

Yin, Yiming, $O Q$

Yu, Qian, OU

Zhang, Cong, 0G, 00

Zhang, Cunlin, 04, OF, OG, OH, OI, OJ, OL, OM, $0 O, O P, O R$

Zhang, Hongfei, $0 \mathrm{G}, 0 \mathrm{O}$ 
Zhang, Liangliang, OR

Zhang, Lijun, 05

Zhang, Lisha, OK

Zhang, Shengbo, OG, OH, $0 \mathrm{O}$

Zhang, Shijing, OR

Zhang, Siyao, OT

Zhang, Weili, 02, 06

Zhang, Xixiang, 02

Zhang, Xuemin, OK

Zhang, Xueqian, 02, 06

Zhang, Yan, OT

Zhang, Ying, 02

Zhang, Zhenwei, OL

Zhang, Zili, OS

Zhao, Changchun, OS

Zhao, Hongwei, OA

Zhao, Xianghui, OA

Zhao, Xiaojing, Ol, OJ

Zhao, Yuejin, 09, OR

Zheng, Zhiyuan, OS

Zhou, Qingli, 04, OM, OP

Zhou, Wei, OQ

Zhou, Zihan, 0

Zhu, Liguo, ON

Zhu, Yong-yuan, 08

Zuo, Jian, Ol, OJ 


\title{
Symposium Committee
}

\author{
General Chairs
}

Tianchu Li, National Institute of Metrology (China)

H. Phillip Stahl, NASA Marshall Space Flight Center (United States)

\section{Conference Co-Chairs}

Songlin Zhuang, Shanghai University of Science and Technology (China)

Liwei Zhou, Beijing Institute of Technology (China)

Shenghua Ye, Tianjin University (China)

Yimo Zhang, Tianjin University (China)

Zheng You, Tsinghua University (China)

Guangjun Zhang, Southeast University (China)

Technical Program Chair

Guofan Jin, Tsinghua University (China)

Technical Program Co-Chairs

Jinxue Wang, SPIE

Tiegen Liu, Tianjin University (China)

Local Organizing Committee Chair

Youhua Wu, China Instrument and Control Society (China)

Local Organizing Committee Co-Chairs

Guoqiang Ni, Beijing Institute of Technology (China)

Daoyin Yu, Tianjin University (China)

General Secretary

Tong Zhang, China Instrument and Control Society (China)

Administrative Vice General Secretary

Yu-nan Sun, Beijing Institute of Technology (China)

Vice General Secretaries

Qun Hao, Beijing Institute of Technology (China)

Yuejin Zhao, Beijing Institute of Technology (China)

Cunlin Zhang, Capital Normal University (China)

Liquan Dong, Beijing Institute of Technology (China) 
Local Organizing Committee

Hongda Chen, Institute of Semiconductors, CAS (China)

Xuping Zhang, Nanjing University (China)

Shangzhong Jin, China Jiliang University (China)

Libo Yuan, Harbin Engineering University (China)

Yumei Wen, Chongqing University (China)

Tian Lan, Beijing Institute of Technology (China)

Cuiling Li, Beijing Institute of Technology (China) 


\title{
Conference Committee
}

\author{
Conference Chairs
}

Cunlin Zhang, Capital Normal University (China)

Xi-Cheng Zhang, University of Rochester (United States)

Zhiming Huang, Shanghai Institute of Technical Physics, CAS (China)

Program Committee

Peter A. R. Ade, Cardiff University (United Kingdom)

Jun-Cheng Cao, Shanghai Institute of Microsystem and Information Technology (China)

Shengliang Chang, Nankai University (China)

Hou-Tong Chen, The Center for Integrated Nanotechnologies (United States)

Jian Chen, Nanjing University (China)

Jianming Dai, University of Rochester (United States)

Jiaguang Han, Tianjin University (China)

Zhi Hong, China Jiliang University (China)

Biaobing Jin, Nanjing University (China)

Weiqi Jin, Beijing Institute of Technology (China)

Ci-Ling Pan, National Tsing Hua University (Taiwan, China)

ShengCai Shi, Purple Mountain Observatory (China)

Fei-jun Song, Daheng New Epoch Technology, Inc. (China)

Jianmin Yuan, National University of Defense Technology (China)

Chao Zhang, University of Wollongong (Australia)

Weili Zhang, Oklahoma State University (United States)

Yan Zhang, Capital Normal University (China)

Zhuoyong Zhang, Capital Normal University (China)

Yuejin Zhao, Beijing Institute of Technology (China)

Kun Zhao, China University of Petroleum (China)

Yiming Zhu, University of Shanghai for Science and Technology

(China)

Zhenwei Zhang (Secretary), Capital Normal University (China)

Session Chairs

1 IRMMW-THz Technologies and Their Applications

Yan Zhang, Capital Normal University (China)

$2 \quad$ IRMMW-THz Technologies and Their Applications

Liangliang Zhang, Capital Normal University (China) 
Proc. of SPIE Vol. 10623 1062301-10 Downloaded From: https://www.spiedigitallibrary.org/conference-proceedings-of-spie on 26 Apr 2023
Terms of Use: https://www.spiedigitallibrary.org/terms-of-use 


\section{Introduction}

The integration of infrared, millimeter wave and terahertz science and technology, has allowed mutual promotion and rapid development. Terahertz science and technology has not been fully explored. Due to its promising applications in spectroscopy, imaging, communications, and nondestructive testing, the tremendous demand has dramatically accelerated the research and development on the smaller terahertz emitter with high-power; the uncooled terahertz detector with high sensitivity; and the portable and robust devices and systems with high speed. In recent years, many reliable new signal sources, detectors, functional devices and systems have continued to emerge. Terahertz technologies already play a crucial role in aerospace, biological medicine, safety inspection, nondestructive testing, cultural relics protection, and next generation wireless communication. At the same time, the research and development of small power terahertz radiation sources, high sensitivity uncooled $\mathrm{THz}$ detectors, and portable high speed equipment and systems are still the key bottlenecks in technology. We are glad to see this subject attracting an increasing amount of attention and interest.

Joint effort made by academia and industry promotes terahertz science and technology development. In this regard, "The Infrared, Millimeter Wave and Terahertz Technologies and Their Applications" conference of OIT 2017 was organized. The conference accepted over 39 papers from different countries/areas of the world, which are focused on novel devices, systems and applications of IRMMW-THz science and technology, and other related research disciplines including plasma, metamaterials, testing and calibration, sensors, imaging, and biomedical technology. We also invited renowned scholars to present their cutting-edge work covering fundamental science such as "Wavelength scaling of terahertz wave generation from laser-induced air plasma," and "Application of infrared nondestructive detection on cultural relic protection." These experts and contributors together made a great feast of intellect.

As the committee chairs, we would like to express our appreciation to the committee members for their support, to the presenters for devoting their precious time to write the intriguing articles, and to the reviewers for their helpful comments. We are also grateful to the staff of SPIE for their efforts in publishing the volume of this Proceedings.

\footnotetext{
Cunlin Zhang

Xi-Cheng Zhang Zhiming Huang
} 
Proc. of SPIE Vol. 10623 1062301-12 Downloaded From: https://www.spiedigitallibrary.org/conference-proceedings-of-spie on 26 Apr 2023
Terms of Use: https://www.spiedigitallibrary.org/terms-of-use 


\title{
Conference Organizers
}

\author{
Organized by \\ Opto-Electronic-Mechanic Technology and System Integration Chapter, CIS \\ (China) \\ Committee on Optoelectronic Technology, COS (China) \\ Committee on Optics, China Ordnance Society (China) \\ Optical Instrument Chapter, CIS (China) \\ Beijing Institute of Technology (China) \\ Tianjin University (China) \\ Tsinghua University (China) \\ Peking University (China) \\ Nanjing University (China) \\ Shanghai Jiao Tong University (China) \\ Zhejiang University (China) \\ Nankai University (China) \\ Capital Normal University (China) \\ Beijing University of Posts and Telecommunications (China) \\ Chongqing University (China) \\ University of Shanghai for Science and Technology (China) \\ Instrument Society of America (United States) \\ Institute of Measurement and Control (United Kingdom) \\ Hong Kong Institution of Engineers (Hong Kong, China) \\ The Society of Measurement and Control (Japan)
}


Proc. of SPIE Vol. 10623 1062301-14 Downloaded From: https://www.spiedigitallibrary.org/conference-proceedings-of-spie on 26 Apr 2023
Terms of Use: https://www.spiedigitallibrary.org/terms-of-use 